\title{
sciendo
}

CIVIL AND ENVIRONMENTAL ENGINEERING REPORTS

E-ISSN 2450-8594

CEER 2021; 31 (2): 0001-0014

DOI: $10.2478 /$ ceer-2021-0016

Original Research Article

\section{BEHAVIOR OF GLULAM BEAMS STRENGTHENED IN BENDING WITH BFRP FABRICS}

\author{
Agnieszka WDOWIAK-POSTULAK ${ }^{1}$, Grzegorz ŚWIT \\ Faculty of Civil Engineering and Architecture, Kielce University of Technology
}

\begin{abstract}
The article presents results of an experimental studies on reinforcement of pine beams made from glued laminated timber with subsurface basalt fibers (BFRP). An experimental research program was presented, in which the bending strength of glued laminated timber of middle and lower quality class was increased after using BFRP basalt fabrics. Thanks to the use of BFRP reinforcement, an average load capacity increased by $47 \%$ and stiffness by $6 \%$ in comparison to non-reinforced elements. Based on the research, it was found that the use of BFRP basalt fabrics is an effective method for strengthening damaged wooden elements. Thus, it is an environmentally friendly method of improving the static work of structural elements by combining wood with other natural materials such as basalt fiber reinforced polymers.
\end{abstract}

Keywords: glued laminated timber, natural materials, BFRP fabrics, reinforcement, bending strength

\section{INTRODUCTION}

In recent years, FRP materials have been innovative raw materials used in the reinforcement of construction timber [1,2]. It should be remembered that the use of reinforcement with FRP and epoxy resins is beneficial for both design and construction on site. The research [3] found that the use of epoxy adhesives is an

${ }^{1}$ Corresponding author: Faculty of Civil Engineering and Architecture, Kielce University of Technology, 25-314 Kielce, Poland, e-mail: awdowiak@tu.kielce.pl, tel. +48 413424480 
effective method of stress transfer between FRP materials and wood. This conclusion was made on the basis of the elimination of stress concentrations during bonding, which may be encountered, for example, when using components such as nails, screws or plugs. It should also be noted that when bonding with epoxy resins the stresses are evenly distributed, allowing for improved consistency between the FRP material and the wood and the epoxy adhesives used [4].

Glass fiber reinforcement (GFRP) is typically used because of its costeffectiveness and better mechanical properties than aramid or carbon fibers [5]. However, a newer type of FRP material is basalt fibers (BFRP). Basalt is a rock formed during the hardening of molten lava emerging from the depths of the earth [6]. It should be noted that wood and basalt are renewable resources [7]. The use of basalt fiber (BFRP) in wooden construction is a little known issue [8]. It should be remembered that the reinforcement of wooden structural elements with a product made of natural material is a method recommended for environmental protection. Basalt, on the other hand, is usually one of the most common types of rock, and basalt fibers have a much lower greenhouse potential than steel or synthetic fibers.

In the literature, the use of bonded BFRP rods was presented in the work of Yeboah et al. [9]. The reinforcement of fifteen bent glued laminated timber beams with BFRP, GFRP and CFRP bars was performed by researchers Fossetti et al. [10]. In the conducted study, it was found that beams with dimensions of $80 \times 130$ $\times 900 \mathrm{~mm}^{3}$ were destroyed after reaching the maximum shear stress of the wood, while the increase in the amount of FRP reinforcement used allowed an increase in the load capacity. Yousef and Saleh [11] investigated the bending strength of $100 \times 200 \times 3000 \mathrm{~mm}^{3}$ wooden beams using GFRP bars with the following diameters: $96.35 \mathrm{~mm}, 9.53 \mathrm{~mm}$ and $12.7 \mathrm{~mm}$. Based on the research, it was found that the samples reinforced with GFRP bars showed increased bending strength. In addition, the tests showed that cracks and knots in the wood caused a decrease in the load-bearing capacity of wooden elements.

Alam et al. [12] tested 36 samples of cracked beams repairing them with a variety of reinforcement materials including steel, CFRP, GFRP and FULCRUM. After the tests, it was found that CFRP and steel showed the best bending strength results. The first research works related to the use of glass fiber reinforcement in wooden elements appeared in the sixties [13-15]. Researchers [14-15] used glass fiber composites to reinforce solid timber beams. In the research, Spaun [16] determined the increase in the tensile strength of bending beams reinforced with glass fibers. Carbon fiber was also used as a reinforcing material in wooden beams [17-18]. In the studies of Triantafillou and Plavris [17], the reinforcement in the form of a steel plate without prestressing was used, while Triantafillou and Deskivic [18] examined the prestressed reinforcement. After the tests, an increase 
in the load-bearing capacity of beams reinforced with unstressed plates was observed. It was also found that the load capacity of Uni-Directional Carbon Fiber Reinforced (CFRP) beams increased from $20 \%$ to $40 \%$ in comparisson to unreinforced beams. Additionally, in the works $[19,20]$ the prestressed sheets were also investigated, and it was found that there was an increase in the loadbearing capacity of beams with the use of prestressed sheets. The fibers used as reinforcement of composite materials are mainly glass and carbon. The first research works that were carried out concerned wooden elements reinforced mainly with glass fiber [21-24]. Subsequently, carbon fiber was introduced to the market, so the amount of research works using this fiber increased $[25,26]$. Research works with the use of aramid fibers can also be found in the literature [27]. On the basis of all the conducted studies, it can be noticed that the use of basalt fiber, primarily in wooden elements, is rare [28]. Haojuni researchers et al. [29] found that FRP reinforcements improve the mechanical properties of reinforced wooden elements. Many other research works on FRP reinforced beams were also carried out, taking into account also the structural and geometric features of construction timber [29-45]. In the studies [46-48], the obtained increase in the load-bearing capacity of reinforced beams depended mainly on the type of the reinforced element or fiber, the reinforcement layout, the degree of FRP reinforcement and the cohesion of the bonding surface between FRP and wood.

Researchers Tingley and Kent [49] achieved a 21.5\% increase in load capacity and 5\% stiffness in wooden beams using CFRP. Fiorelli and Alves [50] determined an increase in the stiffness of beams reinforced with glass fiber (GFRP) ranging from $15 \%$ to $30 \%$. Yusofa and Saleh [51] reinforced the beams with GFRP bars, and achieved an increase in load capacity ranging from $20 \%$ to $30 \%$, and stiffness ranging from $24 \%$ to $60 \%$.

Based on the collected research, it was found that the different test results are caused mainly by the use of different types of reinforcement, as well as the variability of the mechanical properties of the wood used.

This article describes an experimental study to test the effectiveness of heterogeneous glued laminated timber reinforced using BFRP basalt fabrics.

\section{MATERIALS AND METHODS}

Research on the effectiveness of reinforcement of bent wooden beams with different configuration of wood quality classes using basalt fabrics was carried out in the laboratory of the Department of Strength of Materials, Concrete and Bridge Structures of the Kielce University of Technology The tests were carried out on unreinforced (NWB beam series) and reinforced (WB beam series) beams, as shown in Fig. 1. Three repetitions were tested for each beam configuration. 
TYPE NWB

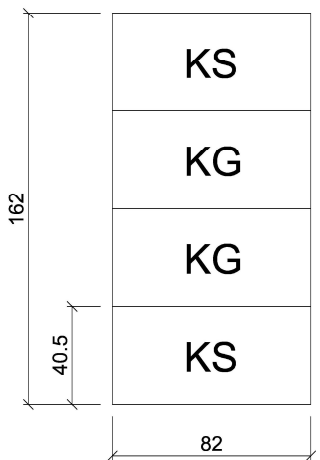

TYPE WB

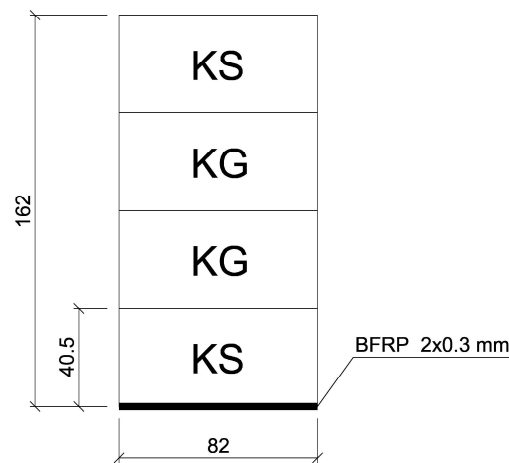

Fig. 1. BFRP reinforcement configuration [dimensions in $\mathrm{mm}$ ]

A universal testing machine was used in the tests, along with two acuators with a pistons area of $50 \mathrm{~cm}^{2}$ each and a maximum applied pressure of $10 \mathrm{MPa}$ made by VEB Werkstoffprufmaschinen Leipzig. The beams were two-point loaded, the distance between the supports was $3 \mathrm{~m}$ (Fig. 2). The beams were subjected to the loading forces $\mathrm{F} / 2$ until the destruction of the glued laminated timber beams.

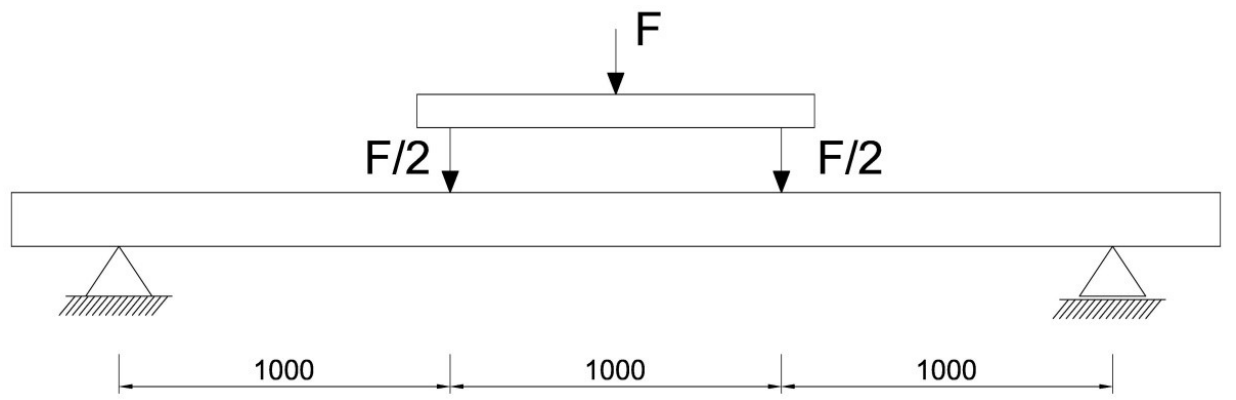

Fig. 2. Diagram of a four-point bending [dimensions in $\mathrm{mm}$ ]

During the research following measurements were made:

- value of the loading force,

- beam displacement in the middle of the span and over a length of $5 \mathrm{~h}$, (h beam section height),

- deformations in wood,

- deformations in the BFRP fabric,

- value of the destructive force,

- the method of failure of the tested beams was determined. 
The sags of the beams were measured using mechanical sensors for a specific loading force F/2 (Fig.3), while the deformation of wood and fabrics BFRP was measured with a mechanical extensometer with a fixed measurement base of the "Demeck" type (Fig. 4).

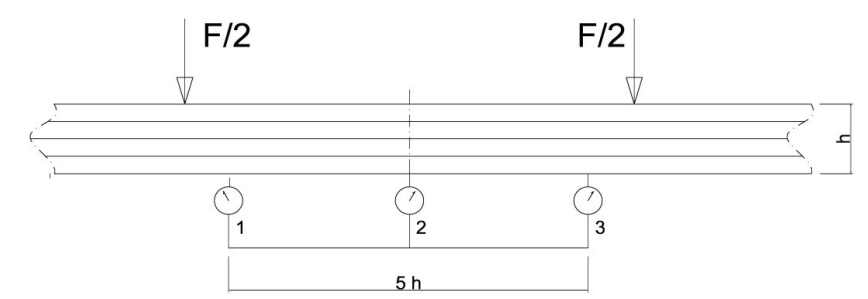

Fig. 3. Arrangement of measuring sensors

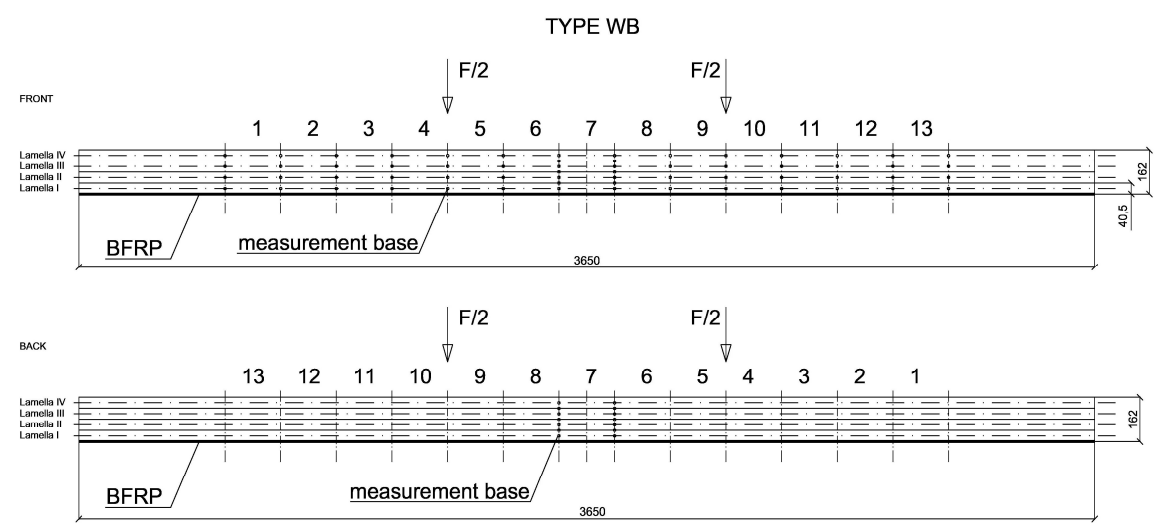

Fig. 4. Distribution of measurement bases for the determination of BFRP wood and fabric deformations [dimensions in $\mathrm{mm}$ ]

\subsection{Unreinforced beams}

Construction timber obtained from Scots pine Pinus sylvestris L. came from the Małopolska natural forest region in Poland and from the beginning and the end of the growing period. All wooden elements have been classified visually, carefully examining all structural and geometric features according to PN-D-94021: 201310 [52], such as: knots, twisted fibers, cracks, resin galls, in barks, galls, blue stain, rot, insect holes, reaction wood (scleroderma), average grain width, density, wane, longitudinal curvature of the sides, longitudinal curvature of planes, transverse curvature with respect to width, twist with respect to width. Then, the coniferous construction timber, intended for the beams, was divided into quality classes: KS - medium quality class, KG - inferior quality class. Glued laminated beams, made 
of elements in various configurations of wood quality (KS and $\mathrm{KG}$ ), have been reinforced with natural fibers in the form of basalt fabrics (BFRP). Each glued beam consisted of four lamellas with a thickness of one layer approximately 40 $\mathrm{mm}$. For glued laminated beams with a cross-section of approx. $82 \times 162 \mathrm{~mm}^{2}$ and a length of approx. $3650 \mathrm{~mm}$, the GL20c class specifications were adopted. All characteristic mechanical properties are in accordance with PN-EN 14080: 2013-07 [53] and are presented in Table 1.

Table 1. Mechanical properties of glued laminated beams

\begin{tabular}{|c|c|}
\hline Properties & $\begin{array}{c}\text { According to } \\
\text { PN-EN 14080:2013-07 }\end{array}$ \\
\hline Bending strength $\left(\mathrm{N} / \mathrm{mm}^{2}\right)$ & 20 \\
\hline \multicolumn{2}{|l|}{ Tensile strength $\left(\mathrm{N} / \mathbf{m m}^{2}\right)$} \\
\hline along the fibres & 15 \\
\hline across the fibres & 0.5 \\
\hline \multicolumn{2}{|l|}{ Compression strength $\left(\mathrm{N} / \mathrm{mm}^{2}\right)$} \\
\hline along the fibres & 18.5 \\
\hline cross the fibres & 2.5 \\
\hline \multicolumn{2}{|l|}{ Modulus of elasticity $\left(\mathrm{N} / \mathbf{m m}^{2}\right)$} \\
\hline along the fibres & 10,400 \\
\hline Shear-modulus (N/mm²) & 650 \\
\hline Density $\mathbf{k g} / \mathrm{m}^{3}$ & 355 \\
\hline
\end{tabular}

\subsection{Beams reinforced with BFRP fiber}

The beams were reinforced with basalt fabrics, the properties of which are presented in Table 2. The beams were reinforced with BFRP fiber with the basis weight of $380 \mathrm{~g} / \mathrm{m}^{2}$ fiber (BT-11/1 P) and epoxy adhesive (LG815 + HG353). The beams were reinforced with two layers of BFRP basalt fibers in the form of fabrics. The reinforcement was glued to the underside of the beams along its entire length with epoxy glue. Before applying the first layer of epoxy glue, the surface of the lamellas was cleaned with a brush and a layer of the "Acetone" solvent was applied to improve the adhesion of BFRP fabrics to wood. After cleaning the wood surface, a pre-layer of epoxy glue with an approximate spread of $0.3 \mathrm{~kg} / \mathrm{m}^{2}$ was applied. Then, a pre-stressed fabric to approx. $40 \mathrm{MPa}$ was applied parallel to the longitudinal direction of the fibers of the beam, and then a layer of epoxy glue 
with a spread of approx. $0.2 \mathrm{~kg} / \mathrm{m}^{2}$ was applied, followed by a second layer of prestressed basalt fabric.

Table 2. Mechanical properties of basalt fabric and epoxy glue

\begin{tabular}{|ccc|}
\hline Feature & BFRP & $\begin{array}{c}\text { Epoxy glue } \\
\text { (LG815 + HG353) }\end{array}$ \\
\hline Density & $2.67 \mathrm{~g} / \mathrm{cm}^{3}$ & - \\
\hline Tensile strength & & - \\
Warp & $1715 \mathrm{~N}$ & - \\
\cline { 2 - 3 } Weft & $980 \mathrm{~N}$ & $110 \div 120 \mathrm{MPa}$ \\
\hline Flexural strength & - & $2700 \div 3300 \mathrm{MPa}$ \\
\hline Modulus of elasticity & do $78 \mathrm{GPa}$ & \\
\hline
\end{tabular}

\section{EXPERIMENTAL RESULTS}

The results concern experimental studies of the effectiveness of reinforcement of non-homogeneous glued laminated timber with the use of BFRP basalt fabrics. NWB beam types were the reference samples for WB reinforced beams. It can be observed that the most common failure pattern was the breaking of the lower fibers in the tension zone, both in reinforced and non-reinforced beams. Additionally, in the case of beams reinforced with BFRP fabrics, the reinforcement fibers also broke. However, only in two beams, only the wood fibers were broken. Usually, the rupture of the fibers took place in the middle of the beam span, mainly at places with significant knots or due to increased fiber inclination, as shown in Figure 5.

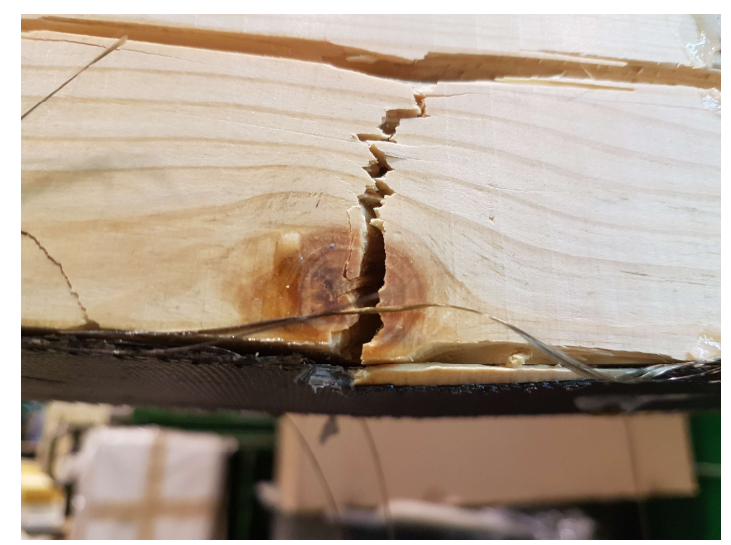

Fig. 5. An example image of the destruction of the WB-2 beam (photo by: WdowiakPostulak) 


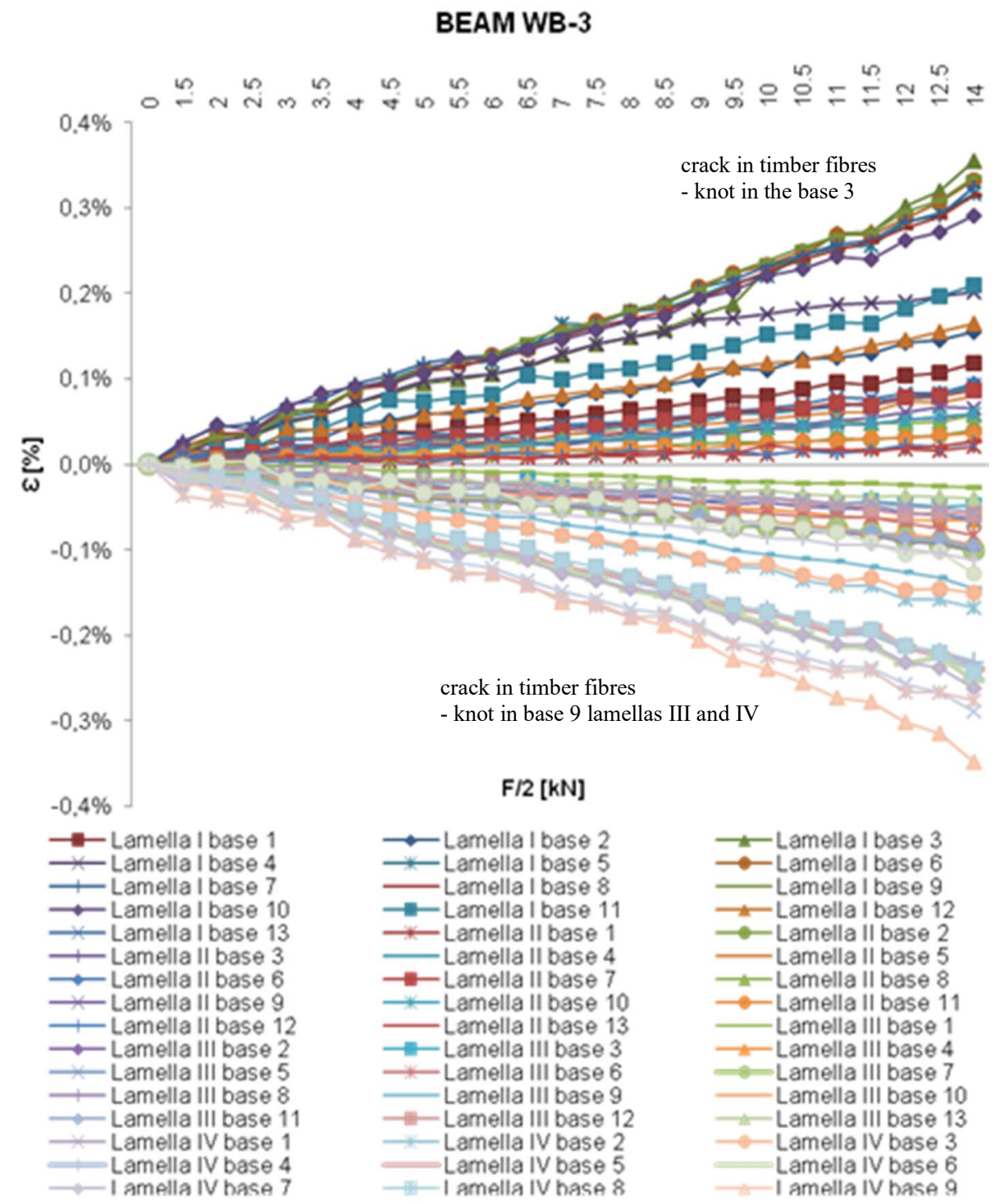

Fig. 6. Diagram of the dependence of $\varepsilon[\%]$ on $F / 2[\mathrm{kN}]$ for the WB-3 reinforced beam

Figure 6 shows a diagram of the dependence of deformations $\varepsilon[\%]$ on the force $\mathrm{F} / 2[\mathrm{kN}]$ for a beam reinforced with WB-3 basalt fabric with a basis weight of 380 $\mathrm{g} / \mathrm{m}^{2}$ in four lamellas along its entire length. As a result of the research, it was found that the values of wood deformation were lower for beams reinforced with BFRP fabrics than for non-reinforced beams. BFRP fabrics significantly reduced 
the distortion of the stretched wood fibers. Taking into account the types of NWB and $\mathrm{WB}$ beams, it can be observed that e.g. for a force $\mathrm{F} / 2$ equal to $10 \mathrm{kN}$, (base 7):

- for the WB1 type, the decrease in tensile strains was about $28 \%$, and in compression strains - about $15 \%$,

- for the WB2 type, the decrease in tensile strains was about $22 \%$ and the increase in compressive strains - about $17 \%$,

- for WB3 type decrease in tensile strains - approx. 33\% and increase in compressive strains - approx. $10 \%$ in relation to NWB type.

Fig. 6 shows the uneven distribution of deformations, mainly caused by the occurrence of wood defects, usually knot cracks (3 lamella I base, 9 lamella III base and IV lamella) and wood fiber cracks. The BFRP fabric absorbed the tensile forces and occurring deformations.

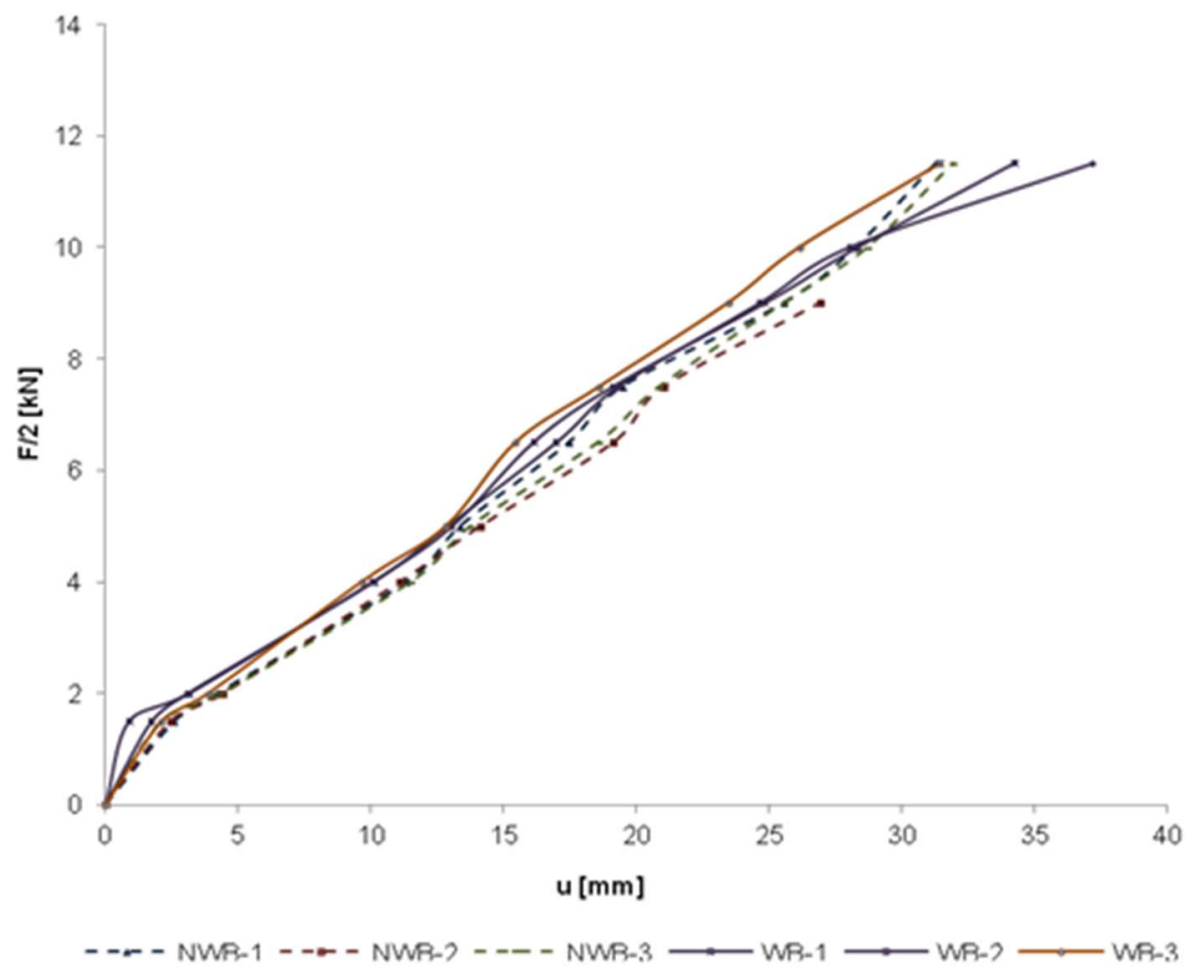

Fig. 7. Graph of the dependence " $\mathrm{u}-\mathrm{F} / 2$ " of the tested beams in the middle of the beam span 
Fig. 7 shows the " $\mathrm{u}-\mathrm{F} / 2$ " dependence curves of the tested beams in the middle of the beam span. The deflection values at the same load level were slightly lower for the beams reinforced with BFRP fabrics than the deflection values of the unreinforced NWB beams. In the middle of the span, for all glued reinforced and unreinforced medium class and lower quality beams, the average deflection value for the force $\mathrm{F} / 2$ equal to $5 \mathrm{kN}$ was respectively $13.34 \mathrm{~mm}$, and for reinforced elements of the middle and lower quality class $-12.93 \mathrm{~mm}$.

\section{CONCLUSIONS}

The experimental studies of four-point bending presented in this article concerned glued laminated beams made of wood obtained from the Małopolska natural forest region in Poland, at the beginning and the end of the growing period, and reinforced with BFRP fabrics in the near-surface.

Experimental studies allowed to define the following conclusions:

1. Glued laminated beams reinforced with BFRP fabric typically exhibited an average increase in load capacity of about $47 \%$ in comparison to unreinforced beams.

2. After the tests, it was found that the increase in the stiffness of the reinforced beams in relation to the non-reinforced beams for the force $\mathrm{F} / 2$ equal to $5 \mathrm{kN}$ amounted to approximately $6 \%$, respectively.

3. It was observed in the research that during the destruction of the two wooden elements, the BFRP fabric was not broken.

4. Samples of unreinforced beams were damaged in the tension zone where knots occur, usually in the middle of the beam span.

5. The beam failure most often occurred in the tensile zone, then the tensile strains amounted to about $0.37 \%$, and in the compressed zone at the strain equal to about $0.29 \%$.

\section{ADDITIONAL INFORMATION}

Funding: The study was completed as part of the implementation of the Miniatura 3 scientific activity, no. 2019/03/X/ST8/00875, financed by the National Science Centre, Poland.

\section{REFERENCES}

1. Ganda, AK, Yeboahb, D, Khoramia, M, Olubanwoa, AO and Lumorc, R 2018. Behaviour of strengthened timber beams using near surface mounted Basalt 
Fibre Reinforced Polymer (BFRP) rebars. Engineering Solid Mechanics 6, 341-352.

2. Hollaway, LC and Teng, JG (Eds.) 2008. Strengthening and rehabilitation of civil infrastructures using fibre-reinforced polymer (FRP) composites. Elsevier.

3. Dempsey, DD and Scott, DW 2016. Wood members strengthened with mechanically fastened FRP strips. Journal of Composites for Construction 10(5), 392-398.

4. Adams, RD 2005. Adhesive bonding: science, technology and applications. Elsevier.

5. Bank, LC 2006. Composites for construction: structural design with FRP materials. John Wiley \& Sons.

6. Subramanian, N 2010. Sustainability of RCC structures using basalt composite rebars. The Master Builder 12(9), 156-64.

7. Zhishen, W, Xin, W and Gang, W 2012. Advancement of structural safety and sustainability with basalt fiber reinforced polymers. CICE 2012, Rome 13, 1529.

8. Raftery, GM and Kelly, F 2015. Basalt FRP rods for reinforcement and repair of timber. Composites Part B: Engineering 70, 9-19.

9. Yeboah, D, Taylor, S, McPolin, D and Gilfillan, R 2013. Pull-out behaviour of axially loaded Basalt Fibre Reinforced Polymer (BFRP) rods bonded perpendicular to the grain of glulam elements. Construction and Building Materials 38, 962-969.

10. Fossetti, M, Minafò, G and Papia, M 2015. Flexural behaviour of glulam timber beams reinforced with FRP cords. Construction and Building Materials 95, 54-64.

11. Yusof, A and Saleh, AL 2010. Flexural strengthening of timber beams using glass fibre reinforced polymer. Electronic Journal of Structural Engineering 10, 45-56.

12. Alam, P, Ansell, MP and Smedley, D 2009. Mechanical repair of timber beams fractured in flexure using bonded-in reinforcements. Composites Part B: Engineering 40(2), 95-106.

13. de la Rosa García, P, Escamilla, AC and González García, MN 2013. Bending reinforcement of timber beams with composite carbon fiber and basalt fiber materials. Composites Part B: Engineering 55, 528-536.

14. Theakston, FH 1965. A feasibility study for strengthening timber beams with fibreglass. Canadian Agricultural Engineering 17-9.

15. Biblis, EJ 1965. Analysis of wood-fiberglass composite beams within and beyond the elastic region. Forest Products Journal 15, 81-8.

16. Spaun, FD 1981. Reinforcement of wood with fibreglass. Forest Products Journal 31(4), 26-33. 
17. Plavris, $\mathrm{N}$ and Trintafillou, TC 1992. FRP Reinforced wood as structural material. Journal of Materials in Civil Engineering 4(3), 300-15.

18. Triantafillou, T, Deskivic, N Prestressed 1992. FRP sheets as external reinforcement of wood members. ASCE Journal of Structural Engineering 118(5), 1270-84.

19. Brunner, M 2002. Theoretical strength limits of timber beams fortified with prestressed artificial fibres. In: Proceedings of WCTE, August, Malaysia.

20. Brunner, M and Schnueriger, M 2004. Timber beams strengthened with prestressed fibres: Delamination. In: Proceedings of WCTE, June, Finland.

21. Gentile, C, Svecova, D, Saltzberg, W and Rizkalla, SH 2000. Flexural strengthening of timber beams using GFRP. In: Proceedings of Advanced Composite Materials in Bridges and Structures, August 637-44, Canda.

22. Hallstrom, S and Grenestedt, JL 1997. Failure analysis of laminated timber beams reinforced with glass fiber composites. Wood Science and Technology 31, 17-34.

23. Johns, KC and Lacroix, S 2000. Composite reinforcement of timber in bending. Canadian Journal of Civil Engineering 27, 899-906.

24. Pavez, A, Ansell, MP and Smedley, D 2009. Mechanical repair of timber beams fractured in flexure using bonded-in reinforcements. Journal of Composites: Part B 40 (2), 95-106.

25. Borri, A, Corradi, M and Grazini, A 2003. FRP reinforcement of wood element under bending loads. In: Proceedings of structural faults and repair, July, Londres.

26. Borri, A, Carrodi, M, Grazini, A 2005. A method for flexural reinforced of old wood beams with CFRP materials. Journal of Composite: Part B 36(2), 143-53.

27. Blab, HJ and Romani, M 2001. Design model for FRP reinforced glulam beams. In: International council for research and innovation in building and construction, working commission W18- timber structures. Meeting 34, Venice, Italy.

28. Carmisciano, S, De Rosa, IM, Sarasini, F, Tamburrano, A and Valente M 2011. Basalt woven fiber reinforced vinylester composites: flexural and electrical proprieties. Mater Design 32, 337-42.

29. Brol, J and Wdowiak, A 2017. The Use of Glass and Aramid Fibres for the Strengthening of Timber Structures; Annals ofWarsaw University of Life Sciences, Forestry and Wood Technology: Warsaw, Poland, 128-13.

30. Brol, J, Nowak, T and Wdowiak, A 2018. Numerical Analysis and Modelling of Timber Elements Strengthened with FRP Materials; Annals of Warsaw University of Life Sciences, Forestry and Wood Technology: Warsaw, Poland, 274-282. 
31. Wdowiak, A 2015. Assessment of technical condition of wooden structures. Proceedings of Transcom 7, 326-332.

32. Wdowiak, A 2016. Analysis of bent timber beam reinforcement with the application of composite materials. Structure and Environmnet 8, 10-16.

33. Wdowiak, A 2018. Structural and strength properties of bent wooden beams reinforced with fibrous composites [Wtaściwości StrukturalnoWytrzymałosciowe Zginanych Belek Drewnianych Wzmocnionych Kompozytami Włóknistymi]. Ph.D. Thesis, Kielce University of Technology, Kielce, Poland.

34. Wdowiak, A and Brol, J 2019. Effectiveness of Reinforcing Bent NonUniform Pre-Stressed Glulam Beams with Basalt Fibre Reinforced Polymers Rods. Materials 12, 3141.

35. Brol, J and Wdowiak-Postulak, A 2019. Old Timber Reinforcement with FRP. Materials 12, 4197, doi:10.3390/ma12244197.

36. Wdowiak, A and Kroner, A 2017. Wpływ niejednorodności struktury zginanych belek z drewna klejonego na efekt ich wzmocnienia. Materiaty Budowlane 1, 87-89.

37. Rudzinski, L and Wdowiak, A 2016. Strength and structural properties of structural timber. Structure and Environmnet 8, 103-108.

38. Wdowiak, A 2016. Using the visual method to sort Polish pine structural sawn timber with respect to strength. Czasopismo Techniczne 2-B, 219-224.

39. Wdowiak, A 2017. Defects in structural timber. Structure and Environmnet 9 , $112-122$.

40. Wdowiak, A and Brol, J 2019. Methods of strength grading of structural timber - comparative analysis of visual and machine grading on the example of Scots pine timber from four natural forest regions of Poland. Structure and Environmnet 11, 210-224.

41. Wdowiak, A 2017. Badanie cech strukturalnych i geometrycznych podczas sortowania wytrzymało' sciowegotarcicy konstrukcyjnej metodą wizualną. Przeglad Budowlany 88, 42-46.

42. Wdowiak, A 2017. Struktura drewna konstrukcyjnego. Journal Of Civil Engineering, Environment And Architecture 34, 365-380.

43. Wdowiak-Postulak, A 2020. Natural Fibre as Reinforcement for Vintage Wood. Materials 13(21), 4799, https://doi.org/10.3390/ma13214799.

44. Wdowiak-Postulak, A and Brol, J 2020. Ductility of the Tensile Zone in Bent Wooden Beams Strengthened with CFRP materials. Materials 13 (23), 5451, https://doi.org/10.3390/ma13235451.

45. Wdowiak-Postulak, A 2021. Basalt Fibre Reinforcement of Bent Heterogeneous Glued Laminated Beams. Materials 14 (1), 51, https://doi.org/10.3390/ma14010051. 
46. Blab, HJ and Romani, M 2000. Load-bearing capacity and strain behaviour of FRP reinforced glulam composite beams. Research report: Schluss bericht AiF-Varhaben 11407/N, Karlsruhe.

47. Dorey, A and Cleng, JJ 1996. The behaviour of GFRP glued laminated timber beams. In: Proceedings of international conference of advanced composite materials in bridges and structures. Montreal, August, 787-94.

48. Belperio, P and Grad, IE 1999. The performance of glulam beams reinforced with carbon fiber. In: Proceedings of pacific timber engineering conference, New Zealand 99-06.

49. Tingley, D and Kent, S 2001. Structural evaluation of fiber reinforced hollow wood beams. In: Proceedings of international conference of advanced composite materials in bridges and structures. Malta, September 367-72.

50. Fiorelli, J and Alves, A 2002. Analysis of the strength and stiffness of timber beams reinforced with carbon fiber and glass fiber. Materials Research, 6(2), 193-202.

51. Yusof, A and Saleh, AL 2010. Flexural strengthening of timber beams using glass fiber reinforced polymer. Electronic Journal of Structural Engineering 10, 45-56.

52. PN-D-94021: 2013-10 Construction timber graded by strength methods [Tarcica konstrukcyjna iglasta sortowana metodami wytrzymałościowymi].

53. PN-EN 14080: 2013-07 Timber structures - Glued laminated timber and glued laminated solid timber - Requirements [Konstrukcje drewniane - Drewno klejone warstwowo i drewno lite klejone warstwowo - Wymagania].

Editor received the manuscript: 09.12.2020 